\title{
Normy KOMPLEMENTARNE KONFERENCJI EPISKOPATÓW StANÓW ZJEDNOCZONYCH I KANADY DO KODEKSU PRAWA KANONICZNEGO Z 1983 R. W ZAKRESIE KSIĘGI II
}

\section{Wstęp}

W funkcjonowaniu konferencji episkopatu ważną kwestią jest podejmowanie uchwał, zwłaszcza formalnych zarządzeń, które przybierają charakter obowiązujących ustaw. Otóż prawodawca kodeksowy postanawia, iż konferencja biskupów może wydawać dekrety ogólne (ustawy) i dekrety ogólne wykonawcze jedynie w tych sprawach, w których przewiduje to prawo powszechne bądź szczegółowe polecenie Stolicy Apostolskiej, wydane przez nią z własnej inicjatywy lub na prośbę samej konferencji ${ }^{1}$. Uchwały, o których mowa, są jednak ważnie podejmowane na zebraniu plenarnym, gdy opowie się za nimi przynajmniej dwie trzecie biskupów należących do konferencji z głosem decydującym. Otrzymują zaś moc obowiązującą dopiero po zaaprobowaniu ich przez Stolicę Apostolską, z chwilą prawnej ich promulgacji; jej sposób oraz czas wejścia dekretów w życie określa sama konferencja episkopatu². Tak więc konferencja biskupów posiada - w granicach określonych w Kodeksie

* Dr hab., Katolicki Uniwersytet Lubelski Jana Pawła II; e-mail: jerzy.adamczyk@kul.pl, https:/ / orcid.org/0000-0003-1415-7378.

1 Codex Iuris Canonici auctoritate Ioannis Pauli PP. II promulgatus (25.01.1983 r.), Acta Apostolicae Sedis (dalej: AAS) 75(1983), pars II, s. 1-317; tekst polski Kodeks Prawa Kanonicznego, przekład polski zatwierdzony przez Konferencje Episkopatu, Poznań 1984, kan. 455 § 1 (dalej: KPK). Ioannes Paulus PP. II, Litterae apostolicae motu proprio datae "Apostolos suos" (21.05.1998 r.), AAS 90(1998), s. 641-658.

2 Kan. 455 § 2-3. W. Góralski, Lud Boży. Kościelne prawo osobowe, Częstochowa 1996, s. 217. 
prawa kanonicznego - władzę ustawodawczą. Jest to władza zwyczajna, a nie delegowana przez prawo, wynikająca z samego urzędu, jakim jest konferencja ${ }^{3}$.

Kodeks prawa kanonicznego z 1983 r. zobowiązuje konferencje biskupie do wydania norm komplementarnych do KPK, m.in. w zakresie księgi II KPK Lud Boży ${ }^{4}$. Niektóre z tych norm kodeksowych obligują konferencje do wydania stosownych przepisów (kompetencyjne normy obligatoryjne), inne zezwalają na emanację takich postanowień (kompetencyjne normy fakultatywne) $)^{5}$. Powstają zatem kwestie: jak zadanie postawione przed konferencjami biskupimi przez prawodawcę kodeksowego w zakresie wydania norm komplementarnych objętych zakresem księgi II KPK wypełniły Konferencje Episkopatów Stanów Zjednoczonych i Kanady? Czy należycie wykorzystały uprawnienia fakultatywne udzielone im przez Kodeks? Czy dostosowały swoje dekrety do miejscowych warunków? Zasygnalizowanym problemom zostanie poświęcony niniejszy artykuł.

\section{Określenie wieku oraz przymiotów mężczyzn świeckich jako kandydatów do posługi lektoratu i akolitatu (kan. 230 § 1 norma obligatoryjna)}

Według kan. 230 § 1 „mężczyźni świeccy, posiadający wiek i przymioty ustalone zarządzeniem konferencji episkopatu, mogą być na stałe przyjęci, przepisanym obrzędem liturgicznym, do posługi lektora i akolity, udzielenie jednak tych posług nie daje im prawa do utrzymania czy wynagrodzenia ze strony Kościoła" ${ }^{.}$.

Konferencja Biskupów Katolickich Stanów Zjednoczonych wydała dekret, gdzie zapisano: „Krajowa Konferencja Biskupów Katolickich,

3 W. Góralski, Lud Boży..., s. 217-218.

4 A. Casaroli (Secrétairerie d'État), Ai presidenti delle Conferenze Episcopali, Communicationes 1983, t. 15, nr 2, s. 135-139. W dokumencie tym opublikowano wykazy spraw, w których konferencje biskupie obowiązane są bądź tylko mogą wydać owe normy, stosownie do ustaleń KPK.

5 Wiele z tych kompetencji ma swoje źródło w dekretach ostatniego soboru lub w jego dokumentach aplikujących te uchwały. Aby uzyskać powyższe informacje zob. Codex Iuris Canonici Fontium annotatione, Città del Vaticano 1989.

6 Zob. L. Gerosa, Canon Law, Münster 2002, s. 124-125. 
zgodnie z przepisem kan. $230 \S 1$, niniejszym postanawia, że mężczyzna świecki, który ma być przyjęty na stałe do posługi lektora lub akolity, winien ukończyć dwudziesty pierwszy rok życia. Kandydat musi również posiadać umiejętności niezbędne do skutecznej proklamacji słowa Bożego lub posługi przy ołtarzu, być w pełni wtajemniczonym członkiem Kościoła katolickiego, być wolnym od wszelkich kar kanonicznych i prowadzić życie, które będzie odpowiadało podjętej służbie"7.

Konferencja Episkopatu Kanady w sprawie wieku oraz przymiotów mężczyzn świeckich jako kandydatów do posługi lektoratu i akolitatu postanowiła, jak następuje: „Zgodnie z przepisem kan. 230 § 1 Kanadyjska Konferencja Biskupów Katolickich niniejszym postanawia, że jeśli mężczyźni świeccy, którzy nie są kandydatami do diakonatu lub prezbiteratu, mają być dopuszczeni do posługi lektora i akolity, muszą mieć ukończone 21 lat. Ponadto mają prowadzić autentyczne życie chrześcijańskie i posiadać uznaną dojrzałość ludzką; dobrą reputację, która pozwoli im przyjąć odpowiedzialność za wspólnotę; muszą być zdolni do współpracy z innymi i posiadać kompetencje niezbędne do wykonywania przeznaczonej im posługi" 8 .

Oceniając normy biskupów USA i Kanady, należy zauważyć, że obie przytoczone normy komplementarne do kan. 230 § 1 są do siebie podobne. Wymagają jednakowego, minimalnego wieku do przyjęcia posługi, stawiają kandydatom do lektoratu i akolitatu wysokie wymagania co do ich kwalifikacji. Wydaje się, że powinno się ustalić także maksymalny wiek do podjęcia tych posług, nadmienić o przygotowaniu początkowym do podjęcia wspomnianych posług i formacji stałej, a także zaznaczyć, że bardziej szczegółowe uregulowania pozostawia się prawodawstwu diecezjalnemu. Powinno się także żądać, w przypadku kandydatów żonatych, zgody żony.

7 United States Conference of Catholic Bishops, Complementary norms, Canon 230 (17 November 1999; recognitio 14 June 2000), http:/ / www.usccb.org/beliefs-and-teachings/ what-we-believe/canon-law/complementary-norms/canon-230 [dostęp: 5.02.2020 r.]. Tłumaczenia tekstów pochodzą od autora.

8 Canadian Conference of Catholic Bishops, Complementary norms to the 1983 Code of Canon Law, Ministries of lector and acolyte, can. 230 § 1, Decree nr 24 (8 October 1986; recognitio 25 April 1987), Ottawa 1996, s. 13. 


\section{Ustalenie trzyletniego programu formacji dla kandydatów do stałego diakonatu (kan. 236 norma obligatoryjna)}

Prawodawca powszechny w kan. 236 zobowiązuje konferencje episkopatu do wydania norm uzupełniających w kwestii trzyletniego programu formacji dla kandydatów do stałego diakonatu. Kan. 236 brzmi: „Kandydaci do stałego diakonatu mają być, zgodnie z przepisami Konferencji Episkopatu, kształtowani do pielęgnowania życia duchowego oraz nauczeni właściwego wykonywania funkcji związanych z tym święceniem: $1^{\circ} \mathrm{mło-}$ dzieńcy przebywając $w$ jakimś specjalnym domu przynajmniej przez trzy lata, chyba że biskup diecezjalny dla poważnych racji inaczej zarządził; $2^{\circ}$ starsi wiekiem mężczyźni, celibatariusze lub żonaci, zgodnie z programem ustalonym przez Konferencję Episkopatu rozłożonym na trzy lata".

Konferencja Biskupów Katolickich Stanów Zjednoczonych w związ$\mathrm{ku} \mathrm{z}$ wymaganiami stawianymi przez kan. 236 opublikowała National directory for the formation, ministry, and life of permanent deacons in the United States, gdzie w dekrecie promulgacyjnym zapisano: „W czerwcu 2003 r. członkowie Konferencji Biskupów Katolickich Stanów Zjednoczonych zatwierdzili Narodowe Dyrektorium ds. Formacji, Życia i Postugi Diakonów Statych w Stanach Zjednoczonych. Działanie to, dokonane zgodnie z kanonem 236 Kodeksu prawa kanonicznego i z nr 15 Ratio fundamentalis institutionis diaconorum permanentium, zostało potwierdzone ad quinquennium experimenti gratia przez Kongregację Edukacji Katolickiej i Kongregację Duchowieństwa (Prot. N. 78/2000), podpisaną przez kardynała Zenona Grocholewskiego, Prefekta Kongregacji Edukacji Katolickiej, i kardynała Darío Castrillóna-Hoyosa, Prefekta Kongregacji ds. duchownych, i datowaną na 30 października 2004 r.

Dekretem z 12 października 2009 r. (Prot. N. 78/2000), podpisanym przez Kardynała Zenona Grocholewskiego, Prefekta Kongregacji Edukacji Katolickiej, i Cláudio Hummesa, Prefekta Kongregacji ds. Duchowieństwa, zatwierdzono ad alterum quinquennio tekst Narodowego Dyrektorium ds. Formacji, Życia i Postugi Diakonów Statych w Stanach Zjednoczonych, zatwierdzony pierwotnie przez Konferencję Biskupów Katolickich Stanów Zjednoczonych w czerwcu 2003 r.".

9 United States Conference of Catholic Bishops, National directory for the formation, ministry, and life of permanent deacons in the United States, Washington 2005, Decree of promulgation (4 November 2009). Zob. W. Donovan, National Directory for the Formation, Ministry, and 
Redaktorzy National directory zaznaczają: „Ten, kto będzie służył jako diakon, wymaga formacji, która sprzyja rozwojowi całej osoby. Dlatego te cztery wymiary formacji powinny być tak wzajemnie powiązane, aby osiągnąć trwałą integrację ich celów w życiu każdego formowanego i w jego posłudze"10. Wyróżnia się następujące wymiary formacji diakońskiej: ludzki, duchowy, intelektualny i pastoralny ${ }^{11}$. Co do czasu trwania formacji początkowej do diakonatu stałego w USA, to autorzy National directory postanawiają: "Zgodnie z Kodeksem Prawa Kanonicznego i Wytycznymi dotyczacymi formacji diakonów stałych wydanymi przez Kongregację Edukacji Katolickiej określa się, że droga kandydata w formacji diakońskiej »musi trwać co najmniej trzy lata, oprócz okresu propedeutycznego, dla wszystkich kandydatów" «"12.

Stosując sie do postanowień kan. 236, Konferencja Episkopatu Kanady wydała dekret, gdzie zapisano: „Zgodnie z przepisami kan. $236 \mathrm{Ka}$ nadyjska Konferencja Biskupów Katolickich wprowadza obowiązkową formację diakonów stałych: 1. Normy przygotowane przez Kanadyjską Konferencję Biskupów Katolickich i zatwierdzone przez Świętą Kongregację Sakramentów 20 stycznia 1969 r. pozostają w mocy; 2. Duchowa i doktrynalna formacja kandydatów do stałego diakonatu trwa co najmniej trzy lata, biorąc pod uwagę wcześniejsze doświadczenia i studia. W tym okresie powinni oni odprawiać coroczne rekolekcje i uczestniczyć w wyznaczonych sesjach formacyjnych; 3 . Kandydat do stałego diakonatu, wspomagany przez swojego kierownika duchowego, podejmuje kroki, aby regularnie karmić się Pismem Świętym i Eucharystią. Powinien zapoznać się z Liturgią Godzin; 4. Zaleca się, aby żonaty kandydat do diakonatu włączył swoją żonę w to przygotowanie doktrynalne i duchowe"13.

Life of Permanent Deacons in the United States (review), The Jurist. Studies in Church Law and Ministry 2008, t. 68, nr 1, s. 313-314. Biskupi USA w Baltimore dnia 12 czerwca 2019 r. zatwierdzili nieco zmienione i dostosowane do aktualnych okoliczności (skandale seksualne, kwestia żon diakonów i ich rola w życiu Kościoła i rodziny diakona, kwestia zaangażowania diakona $\mathrm{w}$ dzieła miłosierdzia) National directory for the formation, ministry, and life of permanent deacons in the United States. Autor korzysta z dostępnego dyrektorium z 2005 r.

10 National directory for the formation, ministry, and life of permanent deacons in the United States, nr 105.

11 Tamże, nr 106-133.

12 Tamże, nr 205.

13 Canadian Conference of Catholic Bishops, Complementary norms to the 1983 Code of Canon Law, Formation of permanent deacons, can. 236, Decree nr 27 (7-9 October 1986; recognitio 10 October 1987), Ottawa 1996, s. 15. 
Należy podkreślić, że biskupi amerykańscy wydając narodowe dyrektorium o formacji do diakonatu stałego, właściwie wypełnili żądanie prawodawcy z kan. 236 KPK. Ważne jest podkreślenie zgody żony na podjęcie formacji diakońskiej i na święcenia diakonatu w przypadku kandydata żyjącego w małżeństwie ${ }^{14}$. Biskupi kanadyjscy wydali także normy zatytułowane National Directory for the Ministry, Formation and Life of Permanent Deacons in Canada. Dyrektorium koordynuje, aktualizuje oraz uzupełnia dane i wytyczne przedstawione wcześniej przez Konferencję Biskupów Katolickich Kanady w sprawie stałych diakonów w Kanadzie, a także zastępuje wcześniejszy Dekret nr $27^{15} \mathrm{w}$ sprawie formacji stałych diakonów, uwzględniając nowe sytuacje i potrzeby. Jego celem jest zapewnienie wytycznych w zakresie formacji, posługi i życia diakonów stałych, jak również podstawowych standardów w zakresie koordynacji i aktualizacji programów i ukierunkowań diakonatu na poziomie lokalnym ${ }^{16}$.

\section{Ustalenie programu kształcenia kapłańskiego (kan. 242 § 1 norma obligatoryjna)}

Prawodawca powszechny zobowiązuje każdą konferencję episkopatu do ustalenia programu kształcenia kapłańskiego. Odnoszący się do tej materii kan. 242 § 1 brzmi: „W poszczególnych krajach powinien obowiązywać program kształcenia kapłańskiego, ustalony przez Konferencję Episkopatu, z uwzględnieniem norm wydanych przez najwyższą władzę kościelną i zatwierdzony przez Stolicę Świętą; powinien on być również do nowych warunków przystosowany, a także za zgodą Stolicy Świętej określać najważniejsze zasady i normy ogólne dotyczące kształcenia seminaryjnego, przystosowane do potrzeb pastoralnych każdego regionu lub prowincji"17.

14 National directory for the formation, ministry, and life of permanent deacons in the United States, nr 205.

15 Canadian Conference of Catholic Bishops, Complementary norms to the 1983 Code of Canon Law, Formation of permanent deacons, can. 236, Decree nr 27, s. 15.

16 Canadian Conference of Catholic Bishops, National Directory for the Ministry, Formation and Life of Permanent Deacons in Canada (10 August 2017), Ottawa 2017.

17 Aktualnie obowiązuje następujący dokument: Kongregacja ds. Duchowieństwa, Dar powołania do kaptaństwa. Ratio fundamentalis institutionis sacerdotalis (8 grudnia 2016 r.), 
Konferencja Biskupów Stanów Zjednoczonych, stosując się do wymogów stawianych przez kan. 242 § 1, opublikowała Program of Priestly Formation $^{18}$, natomiast biskupi kanadyjscy wydali Program for Priestly Formation (Ratio formationis sacerdotalis nationalis) ${ }^{19}$. Przywołane dokumenty nakreślają podstawowe zasady i wytyczne dotyczące formacji kandydatów do kapłaństwa diecezjalnego, aby byli odpowiednio przygotowani do pełnienia przyszłej posługi duszpasterskiej w służbie Kościoła w dzisiejszym społeczeństwie amerykańskim i kanadyjskim. Autorzy zwracają się także do różnych osób zaangażowanych w każdej diecezji w pracę na rzecz budzenia powołań kapłańskich i przygotowania do wstąpienia do seminarium duchownego ${ }^{20}$. Trzeba dodać, że wspomniane wyżej normy krajowych programów formacji kapłańskiej są realizacją nie tylko normy kan. 242 § 1, lecz także wyrazem korzystnej decentralizacji prawa kanonicznego, rzecz jasna, bez naruszania przy tym władzy nadzorczej Stolicy Apostolskiej $^{21}$.

Watykan 2016. Omawiane w artykule normy Konferencji Episkopatów USA i Kanady w zakresie kan. 242 \& 1 odnosiły sie do obowiązującego wtedy: Sacra Congregazione per L'educazione Cattolica, Ratio fundamentalis institutionis sacerdotalis (6.01.1970 r.), AAS 62(1970), s. 321-384, editio apparata post Codicem iuris canonici promulgatum (19 marzo 1985), Typis Polyglottis Vaticanis 1985.

18 United States Conference of Catholic Bishops, Program of Priestly Formation. Fifth Edition, Washington 2006. Konferencja Katolickich Biskupów Stanów Zjednoczonych opublikowała piąte wydanie w 2005 r. Z tego dostępnego dla autora wydania korzysta się w niniejszym artykule. Szóste wydanie zostało zaprojektowane na 2020 r. Por. Models of Priestly Formation. Assessing the Past, Reflecting on the Present, and Imagining the Future, red. D. Marmion, M. Mullaney, S. Ryan, Collegeville 2019, s. 52.

19 Canadian Conference of Catholic Bishops, Program for Priestly Formation (Ratio formationis sacerdotalis nationalis), Ottawa 2014. Ten program został zatwierdzony przez Stolicę Apostolską na okres dwóch lat, po czym miał zostać zrewidowany w celu dostosowania go do publikacji Dar powołania do kaptaństwa. Ratio fundamentalis institutionis sacerdotalis, wydanej przez Kongregację Duchowieństwa w 2016 r. Z tego dostępnego dla autora wydania (2014) korzysta się w niniejszym artykule.

20 Ze względu na szczupłość ram niniejszego artykułu dokumenty te nie sposób omówić szczegółowo.

21 Zob. Ch. Onyems Okwuru, The Responsibilities and Significance of the Congregatio pro Clericis in the life and ministry of the diocesan clergy, Bloomington 2012, s. 130. 


\section{Określenie części liturgii godzin, którą powinni odmawiać diakoni stali (kan. 276 § 2, nr 3 norma obligatoryjna)}

Prawodawca kodeksowy zobowiązuje konferencje episkopatu do określenia części liturgii godzin, którą powinni odmawiać diakoni stali. Kan. 276 § 2, nr 3 brzmi: „kapłani a także diakoni przygotowujący się do prezbiteratu mają obowiązek odmawiać codziennie liturgię godzin, zgodnie z własnymi i zatwierdzonymi księgami liturgicznymi, natomiast diakoni stali mają odmawiać jej część, określoną przez Konferencję Episkopatu"22.

Zakres, w jakim diakoni stali są zobowiązani do odmawiania liturgii godzin, pozostawia się do decyzji konferencji episkopatu, w przeciwieństwie do kapłanów i diakonów przygotowujących się do prezbiteratu, którzy mają obowiązek odmawiać codziennie całą liturgię godzin, zgodnie z własnymi i zatwierdzonymi księgami liturgicznymi.

Biskupi Stanów Zjednoczonych wypełniając wolę najwyższego prawodawcy, zawartą w kan. 276 § 2, nr 3, postanowili, że: „Stali diakoni mają obowiązek włączyć do swojej codziennej modlitwy te części Liturgii godzin, które są znane jako Modlitwa Poranna i Wieczorna. Stali diakoni mają obowiązek modlić się za Kościół powszechny. O ile to możliwe, powinni prowadzić te modlitwy wraz ze wspólnotą, do której zostali przydzieleni" 23 .

Konferencja Episkopatu Kanady co do liturgii godzin diakonów stałych zarządza, jak następuje: „Zgodnie z przepisami kan. 276 § 2, nr 3 Kanadyjska Konferencja Biskupów Katolickich niniejszym postanawia, że diakoni stali mają obowiązek codziennego odmawiania porannej i wieczornej modlitwy z liturgii godzin" ${ }^{24}$.

Przytoczone dekrety, zgodnie z wolą prawodawcy, stosują się wyłącznie do diakonów permanentnych, gdyż diakoni przejściowi są zobowiązani do integralnej modlitwy brewiarzowej. Dekret amerykański oprócz

22 Por. kan. $1174 \S 1$.

23 United States Conference of Catholic Bishops, Complementary norms, Canon $276 \S 2$, nr 3 (June 2003; recognitio 30 October 2004), http:/ / www.usccb.org/beliefs-and-techings/ what-we-believe/canon-law/complementary-norms/canon-276 [dostęp: 5.02.2020 r.]. Jest to norma zaczerpnięta z promulgowanego National directory for the formation, ministry, and life of permanent deacons in the United States, nr 90.

${ }_{24}$ Canadian Conference of Catholic Bishops, Complementary norms to the 1983 Code of Canon Law, Liturgy of the hours for permanent deacons, can. 276 § 2, nr 3, Decree nr 17 (8 October 1986; recognitio 25 April 1987), Ottawa 1996, s. 21. 
liturgii godzin nakłada na tych duchownych dodatkowe modlitwy. Wydaje się, że biskupi obu konferencji właściwie uwzględnili okoliczności życia diakonów stałych na odcinku modlitwy liturgii godzin w ich dążeniu do świętości.

\section{Określenie stroju dla duchownych (kan. 284 norma obligatoryjna)}

Prawodawca kodeksowy w kan. 284 zarządza, iż „Duchowni powinni nosić odpowiedni strój kościelny, według przepisów wydanych przez Konferencję Episkopatu a także zwyczajów miejscowych, zgodnych z przepisami prawa" ${ }^{25}$. Jednakże diakoni stali nie są związani przepisami kan. 284 (co do noszenia stroju duchownego), chyba że prawo partykularne co innego postanawia ${ }^{26}$. Odnośnie do zwyczaju kanonicznego, co do stroju duchownego, nie można za taki uznać zwyczaju, który wprowadza „powszechną praktykę nieużywania stroju duchownego, nawet jeśli jest on przepisany" 27.

Ponieważ natura stanu duchownego zakłada zaangażowanie duchownych w służbę publiczną, która zasadniczo jest pełniona dla wszystkich, dlatego zobowiązuje się ich, aby nosili strój duchowny, tak aby ich stan i godność mogły być uznane i respektowane. To kanoniczne zobowiązanie duchownych do noszenia stroju duchownego służy nie tylko wyraźnemu odróżnieniu ich od świeckich noszących inne, świeckie ubrania, lecz także przyczynia się do podkreślenia godności duchownego w jego zewnętrznym zachowaniu lub w wykonywaniu jego posługi ${ }^{28}$.

Biskupi Stanów Zjednoczonych, stosując się do tego przepisu, postanowili, co następuje: „Narodowa Konferencja Biskupów Katolickich,

25 Odnośnie do ukazania motywacji, ewolucji historycznej i aktualnej dyscypliny kościelnej dotyczącej stroju duchownego zob. interesującą publikację pracy doktorskiej: M. De Santi, L'abito ecclesiastico. Sua valenza e storia, Ravenna 2004. Autor pisze, że celem jego pracy jest „potwierdzić głębokie znaczenie dyscypliny kościelnej w tym zakresie [stroju kościelnego - J.A.], pomagając odkryć na nowo jej znaczenie i przydatność w życiu kapłańskim". Tamże, s. 16.

26 Kan. 288; por. Ch. Onyems Okwuru, The Responsibilities and Significance..., s. 240-241;

W. Ditewig, 101 Questions and Answers on Deacons, New York 2004, s. 55-57.

27 M. De Santi, L'abito ecclesiastico..., s. 263.

28 Ch. Onyems Okwuru, The Responsibilities and Significance..., s. 237-238. 
zgodnie z nakazami kan. 284, niniejszym postanawia, że bez uszczerbku dla postanowień kan. 288 duchowni mają ubierać się zgodnie z ich świętym powołaniem. $W$ obrzędach liturgicznych duchowni powinni nosić szatę przepisaną w odpowiednich księgach liturgicznych. Poza funkcjami liturgicznymi czarny garnitur i rzymska koloratka są zwykłym strojem kapłanów. Używanie sutanny leży w gestii duchownego. W przypadku duchownych zakonnych należy przestrzegać ustaleń ich właściwych instytutów lub stowarzyszeń w odniesieniu do noszenia habitu zakonnego" 29 .

Należy zauważyć, że przywołany dekret nic nie mówi o stroju duchownym diakonów stałych. I jest to słuszne, gdyż oni tym przepisom nie podlegają. Kan. 288 stanowi: „Diakoni stali nie są związani przepisami kanonów 284 [...], chyba że prawo partykularne co innego postanawia". National directory for the formation, ministry, and life of permanent deacons in the United States postanawia: „Kodeks prawa kanonicznego nie zobowiązuje stałych diakonów do noszenia stroju duchownego. Ponadto, ponieważ są oni wyeksponowani i aktywni w świeckich zawodach i w społeczeństwie, Konferencja Biskupów Katolickich Stanów Zjednoczonych precyzuje, że diakoni stali powinni przypominać wiernych świeckich w ubiorze i sprawach dotyczących stylu życia. Każdy biskup diecezjalny powinien jednak określić i ogłosić wszelkie wyjątki od tego prawa, a także określić odpowiedni strój duchowny, jeśli ma być noszony" ${ }^{30}$. Z uwagi na to, że mogą wystąpić wyjątki od reguły kan. 288, wydaje się, że norma komplementarna do kan. 284 biskupów USA powinna o tym wspominać.

Konferencja Episkopatu Kanady w sprawie stroju duchownego stwierdza, jak następuje: „Zgodnie z przepisami kan. 284 Kanadyjska Konferencja Biskupów Katolickich niniejszym postanawia, że bez uszczerbku dla postanowień kan. 288 duchowni mają się ubierać w taki sposób, aby można było ich zidentyfikować jako duchownych" ${ }^{31}$. W oficjalnym komentarzu

29 United States Conference of Catholic Bishops, Complementary norms, Canon 284 (18 November 1998; recognitio 29 September 1999), http://www.usccb.org/beliefsand-teachings/what-we-believe/canon-law/complementary-norms/canon-284 [dostęp: 5.02.2020 r.]; por. R. Cunningham, Commentary on canon 284, w: New Commentary on the Code of Canon Law, red. J. Beal, New York 2000, s. 373.

30 National directory for the formation, ministry, and life of permanent deacons in the United States, nr 89.

31 Canadian Conference of Catholic Bishops, Complementary norms to the 1983 Code of Canon Law, Ecclesiastical dress, can. 284, Decree nr 25 (7-9 October 1986; recognitio 10 October 1987), Ottawa 1996, s. 23. 
do przywołanego Dekretu nr 25 zamieszczonym w publikacji Complementary norms to the 1983 Code of Canon Law, która jest źródłem dla niniejszego artykułu, zapisano: „1. Dekret odnosi się do wszystkich duchownych. Jednakże, na mocy przepisów kan. 288, diakoni stali nie są związani jego przepisami. 2. Dekret nie precyzuje, co stanowi strój duchowny. Zamiast tego wymaga znaku identyfikacyjnego, który może różnić się w zależności od miejsca. Tym znakiem może być rzymska koloratka, krzyżyk lub krzyż noszony w klapie lub na szyi. W przypadku duchownego, który należy do instytutu zakonnego, może składać się z insygniów instytutu" ${ }^{32}$.

Wydaje się, że norma biskupów kanadyjskich jest zbyt ogólnikowa, a co za tym idzie dopuszcza wiele rozwiązań, czasem niezgodnych z mens legislatoris, co może prowadzić do nadużyć, także do zarzucenia stroju duchownego, którego noszenie jest obowiązkiem prawnym. Komentarz, choć sugeruje różne rozwiązania, nie jest normą kanoniczną.

\section{Wydanie norm ramowych dla statutów rad kapłańskich (kan. 496 norma obligatoryjna)}

Kolejną normą obligatoryjną dla konferencji episkopatu jest przepis kan. 496, gdzie postanawia się: „Rada kapłańska powinna posiadać własne statuty, zatwierdzone przez biskupa diecezjalnego i uwzględniające normy wydane w tej sprawie przez Konferencję Episkopatu".

Biskupi Stanów Zjednoczonych respektując postanowienia kan. 496, podjęli następującą decyzję: „Krajowa Konferencja Biskupów Katolickich, zgodnie z przepisami kan. 496, niniejszym postanawia, że statut rady kapłańskiej ma zawierać postanowienie, że rada zbiera się co najmniej cztery razy $\mathrm{w}$ roku, aby skutecznie realizować swój cel pomocy biskupowi diecezjalnemu w zarządzaniu diecezją zgodnie z normą prawa (zob. kan. 495 § 1). Statuty rady kapłańskiej mają być opracowane zgodnie z postanowieniami kan. 497 do 501"33.

32 Tamże.

33 United States Conference of Catholic Bishops, Complementary norms, Canon 496 (June 2003; recognitio 29 September 1999), http:/ / www.usccb.org/beliefs-and-teachings/ what-we-believe/canon-law/complementary-norms/canon-496 [dostęp: 5.02.2020 r.]. 
Z kolei Konferencja Episkopatu Kanady zarządza: „Zgodnie z przepisami kan. 496 Kanadyjska Konferencja Biskupów Katolickich niniejszym postanawia, że Rada Kapłańska w każdej diecezji będzie miała Komitet Wykonawczy, któremu przewodniczyć będzie biskup diecezji lub jego delegat. Rada Kapłańska ma się spotykać co najmniej dwa razy w roku; ma głos doradczy. Kadencja kapłanów wybranych do Rady Kapłańskiej lub mianowanych przez biskupa diecezjalnego jest nie krótsza niż dwa lata i nie dłuższa niż pięć lat, z możliwością przedłużenia. Funkcje Rady Kapłańskiej są skoordynowane z zadaniami innych grup diecezjalnych"34.

Należy zauważyć, że norma konferencji kanadyjskiej jest bogatsza niż analogiczna norma amerykańska. Cenne jest tu ustanowienie komitetu wykonawczego rady, któremu przewodniczyć ma biskup diecezji lub jego delegat. Dekret wzywa radę do koordynacji z innymi grupami diecezjalnymi. Należą do nich: diecezjalna rada duszpasterska (kan. 511), kolegium konsultantów (kan. 502), diecezjalna rada ekonomiczna (kan. 492), kapituła kanoników (jeśli taka istnieje - kan. 503) oraz wszelkie inne organizmy diecezjalne utworzone w celu promowania duszpasterstwa w Kościele partykularnym. Obie przytoczone normy mają charakter ramowy, służą pewnemu zasadniczemu ujednoliceniu instytucji rad kapłańskich na terenie konferencji episkopatu, a jednocześnie pozostawiają biskupowi diecezjalnemu dużą swobodę w odpowiednim kształtowaniu statutu rady, gdyż to on ten dokument aprobuje. Ważny w przypadku normy z USA jest nakaz częstych, bo co najmniej czterokrotnych w ciągu roku spotkań rady, aby mogła skutecznie realizować swój cel pomocy biskupowi diecezjalnemu w zarządzaniu diecezją. Chroni to także samą radę od skostnienia, formalizmu i zniechęcenia. Wydaje się, że normy winny podać minimalną i maksymalną liczbę członków rady kapłańskiej. Liczba przewidzianych spotkań rady podana w przytoczonych dekretach jest minimalna: rzeczywista liczba posiedzeń będzie zależała od poszczególnych statutów lub od lokalnej sytuacji.

34 Canadian Conference of Catholic Bishops, Complementary norms to the 1983 Code of Canon Law, Statutes of presbyteral councils, can. 496, Decree nr 26 (7-9 October 1986; recognitio 10 October 1987), Ottawa 1996, s. 33. 


\section{Wydanie norm $w$ sprawie utrzymania i mieszkania proboszczów przechodzących na emeryturę (kan. 538 § 3 norma obligatoryjna)}

Prawodawca kodeksowy obliguje konferencje episkopatu do wydania norm w sprawie utrzymania i mieszkania proboszczów przechodzących na emeryturę, co formalizuje w kan. 538 § 3, w którym zarządza: „Proboszcz, po ukończeniu siedemdziesiątego piątego roku życia, jest proszony o złożenie zrzeczenia się urzędu na ręce biskupa diecezjalnego, który rozważywszy wszystkie okoliczności osoby i miejsca, powinien zadecydować o przyjęciu lub odłożeniu zrzeczenia. Biskup diecezjalny obowiązany jest zapewnić zrzekającemu się odpowiednie utrzymanie i mieszkanie, mając na uwadze normy ustalone przez Konferencję Episkopatu". Przytoczony kanon nakazuje konferencjom biskupów wydanie norm dotyczących utrzymania emerytowanych proboszczów, które musi zapewnić biskup diecezjalny. Jest to szczególny aspekt wynagrodzenia duchownych.

W związku z przywołanym kanonem Krajowa Konferencja Biskupów Katolickich Stanów Zjednoczonych zadecydowała: „Zgodnie z zapisami kan. 538 § 3 Krajowa Konferencja Biskupów Katolickich upoważnia biskupów diecezjalnych do opracowania wytycznych diecezjalnych dotyczących przechodzenia na emeryturę kapłanów zgodnie z postanowieniami Norms for Priests and Their Third Age" 35 .

Natomiast biskupi kanadyjscy zarządzili, jak następuje: „Zgodnie z przepisami kan. 538 § 3 oraz postanowieniami kan. 281 § 2 Kanadyjska Konferencja Biskupów Katolickich niniejszym postanawia, że biorąc pod uwagę zasady sprawiedliwości naturalnej i słuszności, jak również tradycje i okoliczności każdej diecezji: 1. Każdy biskup diecezjalny dopilnuje, aby opracowany został specjalny i zindywidualizowany plan, który zapewni odpowiednie utrzymanie i mieszkanie wszystkim emerytowanym księżom inkardynowanym do jego diecezji; pod uwagę brane są dostępne rządowe programy emerytalne, publiczne programy emerytalne i inne programy świadczeń socjalnych; 2. każdy biskup diecezjalny

35 United States Conference of Catholic Bishops, Complementary norms, Canon 538 § 3 (November 1987; recognitio 19 January 1988), http:/ / www.usccb.org/beliefs-and-techings / what-we-believe/canon-law/complementary-norms/canon-538 [dostęp: 5.02.2020 r.]. Norms for Priests and Their Third Age zostały promulgowane 23 lutego 1988 r. Bishops' Committee on Priestly Life and Ministry Staff, Catholic Church. National Conference of Catholic Bishops, Norms for Priests and Their Third Age (23 February 1988), Washington 1988. 
dba również o to, aby kapłani inkardynowani w diecezji, którzy staną się niepełnosprawni przed osiągnięciem przepisanego wieku emerytalnego, otrzymali wystarczającą pomoc, aby zapewnić im odpowiednie utrzymanie i mieszkanie, biorąc pod uwagę wszelkie programy pomocy społecznej, do których mogą być uprawnieni; 3. zarządzanie i kontrolę prawidłowości funkcjonowania funduszy emerytalnych i rentowych powierza się osobom, które zostały uznane za rzeczywiście kompetentne w tej dziedzinie" 36 .

W oficjalnym komentarzu do przywołanego Dekretu nr 31 zamieszczonym w publikacji Complementary norms to the 1983 Code of Canon Law zapisano: „Dekret ten, wprowadzający w życie jeden z głównych wymogów Kodeksu prawa kanonicznego z 1983 r., dotyczący obowiązków biskupa diecezjalnego wobec emerytowanych i chorych księży inkardynowanych do diecezji, pozostawia każdemu biskupowi wybór najodpowiedniejszego sposobu realizacji celu prawa. Kan. 1274 przewiduje, że w razie potrzeby kilka diecezji może się zjednoczyć w celu utworzenia wspólnych funduszy emerytalnych i kompensacyjnych, ale nie jest to uregulowane w Kanadzie. Dekret stosuje się bezpośrednio do księży inkardynowanych w diecezji, niezależnie od tego, czy faktycznie pracują tam, czy gdzie indziej. W szczególnych przypadkach można jednak wprowadzić odpowiednie zmiany w przepisach, jak np. w przypadku, gdy ksiądz jest zaangażowany w działalność duszpasterską, czy gdy istnieją już odpowiednie programy świadczeń pracowniczych. Zarządzanie tymi dwoma funduszami [emerytalnym i kompensacyjnym - J.A.] ma być powierzone prawdziwie kompetentnym osobom, wybranym lub zatwierdzonym przez biskupa diecezjalnego. Generalnie, jeden lub więcej księży diecezjalnych zasiada w zarządzie nadzorującym te fundusze. Adekwatność tych planów emerytalnych i kompensacyjnych powinna być okresowo weryfikowana" ${ }^{37}$.

36 Canadian Conference of Catholic Bishops, Complementary norms to the 1983 Code of Canon Law, Support for retired priests Canon, can. 538, Decree nr 31 (23 October 1984; recognitio 8 March 1985), Ottawa 1996, s. 41.

37 Tamże. 


\section{Powierzenie kapitule katedralnej zadań kolegium konsultorów (kan. 502 § 3 norma fakultatywna)}

Kodeks prawa kanonicznego w kan. 502 § 3 zawiera postanowienie: „Konferencja Episkopatu może zarządzić, by zadania konsultorów zostały powierzone kapitule katedralnej". Jest to kompetencja powierzona konferencjom episkopatu w sprawach organizacji kościelnej, która ma charakter zalecenia. Dopuszcza się tu możliwość ustalenia, że funkcje kolegium konsultorów zostają powierzone kapitule katedralnej, przedłużając w pewnej mierze normy Kodeksu prawa kanonicznego z 1917 r. ${ }^{38}$

Konferencja Biskupów Katolickich Stanów Zjednoczonych nie skorzystała z możliwości zawartej w przytoczonej normie kanonicznej, to znaczy, że funkcje kolegium konsultorów pełnią kapłani zgodnie z kan. 502 $\S 1$. Jest to zrozumiałe, gdyż $w$ Stanach Zjednoczonych nie istnieją kapituły katedralne. W. Fanning pisał, że „w Stanach Zjednoczonych kapituły katedralne nie zostały jak dotąd utworzone. W 1883 r. Propaganda [Kongregacja Rozkrzewiania Wiary - J.A.] skonsultowała się z amerykańskimi biskupami co do celowości ich erygowania, ale prałaci uznali, że nie był to jeszcze odpowiedni czas"39.

Natomiast Kanadyjska Konferencja Biskupów Katolickich ustosunkowała się do normy kan. 502 § 3 i wydała dekret generalny o następującej treści: „Zgodnie z przepisami kan. 502 Kanadyjska Konferencja Biskupów Katolickich niniejszym postanawia, że tam, gdzie Kapituły Kanoników zostały legalnie ustanowione w Kanadzie, mogą one otrzymać rolę przydzieloną Kolegium Konsultorów, jeśli biskup diecezjalny tego sobie życzy" 40 .

Wydaje się, że norma biskupów kanadyjskich jest słuszna, gdyż pozostawia biskupowi diecezjalnemu kwestię wprowadzenia w życie w swojej diecezji kan. 502 § 3. Zważywszy na to, że głosowanie nad kodeksowymi

38 J. Martín de Agar, Estudio comparado de los decretos generales de las conferencias episcopales, Ius Canonicum 1992, t. 32, nr 63, s. 193.

39 W. Fanning, Chapter, w: The Catholic Encyclopedia, t. 3. Brownson-Clairvaux, New York 1913, s. 1491; por. D. Burkard, Die Domkapitel und das "regimen ecclesiasticum”. Thesen $z u$ Wandel und Kontinuität einer alten Institution, Rottenburger Jahrbuch für Kirchengeschichte 2014, t. 33, s. 177.

40 Canadian Conference of Catholic Bishops, Complementary norms to the 1983 Code of Canon Law, College of consultors, can. 502 § 3, Decree nr 4 (23 October 1984; recognitio 8 March 1985), Ottawa 1996, s. 37. 
normami kompetencyjnymi dla konferencji biskupów nie jest jednomyślne, ale jest aktem kolegialnym, gdzie wymagana jest nie jednomyślność, ale dwie trzecie głosów ${ }^{41}$, biskup, który nie zgadza się z postanowieniami konferencji, może swobodnie powierzać w swojej diecezji funkcje kolegium konsultorów kapitule katedralnej.

\section{Ustalenie, iż mianowanie proboszczów będzie się dokonywać na czas określony (kan. 522 norma fakultatywna)}

Kolejną normą fakultatywną powierzoną przez KPK konferencji episkopatu jest regulacja problematyki kadencyjności proboszczów. Stosowny przepis zawarty w kan. 522 brzmi: „Proboszcz winien cieszyć się stałością i dlatego ma być mianowany na czas nieokreślony. Na czas określony biskup diecezjalny może mianować tylko wtedy, gdy zezwala na to dekret Konferencji Episkopatu".

Konferencja Biskupów Katolickich Stanów Zjednoczonych, korzystając z normy zapisanej w kan. 522, wydała dekret ogólny: „Poszczególni ordynariusze mogą mianować proboszczów na sześcioletnią kadencję. Możliwość przedłużenia tej kadencji pozostawia się do decyzji biskupa diecezjalnego" 42 .

Należy zauważyć, że dekret biskupów amerykańskich mówi o ordynariuszach, a więc o wikariuszach generalnych i wikariuszach biskupich, którzy - według tego dokumentu - mogą mianować proboszczów na sześcioletnią kadencję. Nie jest to słuszne, gdyż kompetencja do mianowania proboszczów, czyli powierzenia im urzędu, i to w formie swobodnego nadania, przysługuje tylko biskupowi diecezjalnemu ${ }^{43}$ i innym rządcom Kościołów partykularnych, którzy są zrównani z biskupem diecezjalnym ${ }^{44}$. Na mocy prawa wspomniana władza nie przysługuje więc wikariuszowi generalnemu ani wikariuszowi biskupiemu, chyba że otrzymali

41 Kan. 119, kan. 131.

42 United States Conference of Catholic Bishops, Complementary norms, Canon 522 (14 November 1983; recognitio 16 May 1984), http:/ / www.usccb.org/beliefs-andteachings/ what-we-believe/canon-law/complementary-norms/canon-522 [dostęp: 5.02.2020 r.]; por. L. Porter, The assault on priesthood. A biblical and theological rejoinder, Eugene 2012, s. 48.

43 Kan. 523.

44 Kan. $381 \S 2$. 
specjalny mandat od swego biskupa diecezjalnego. Administratorowi diecezjalnemu i tym, którzy rządzą diecezją $\mathrm{w}$ sytuacji sede vacante lub sede impedita, kompetencje te przysługują dopiero po upływie roku od zawakowania diecezji lub zaistnienia przeszkody w sprawowaniu władzy przez biskupa diecezjalnego ${ }^{45}$.

Z kolei Kanadyjska Konferencja Biskupów Katolickich odnośnie do kan. 522 postanowiła: „Zgodnie z przepisami kan. 522 Kanadyjska Konferencja Biskupów Katolickich niniejszym postanawia, że proboszczowie parafii mogą być mianowani na odnawialną sześcioletnią kadencję; decyzja taka zostanie podjęta po konsultacji z radą kapłańską" ${ }^{46}$.

Komentując przywołany dekret - normę komplementarną, w Kanadzie proboszczowie mogą być obecnie mianowani na jeden $\mathrm{z}$ dwóch sposobów: albo na czas nieokreślony, albo na sześcioletnią, odnawialną kadencję. Dekret nie przewiduje okresów dłuższych lub krótszych. Jednakże, przed wprowadzeniem w życie dekretu, biskup diecezjalny musi skonsultować się z radą kapłańską; dokument powyższy nie wymaga zgody rady, a jedynie konsultacji z nią. Chociaż nie została określona ilość kadencji sprawowania urzędu przez proboszcza, to jednak mens legislatoris jest taka, że w przypadku nominacji kadencyjnej proboszcz, po kilku latach pracy $\mathrm{w}$ danej parafii, może spodziewać się przeniesienia do innej. Proboszczowie, którzy zostali mianowani do swoich obecnych parafii w ramach innego systemu nominacyjnego, winni przestrzegać warunków tego powołania do momentu jego wygaśnięcia ${ }^{47}$.

\section{Wydanie przepisów co do rodzaju i sposobu prowadzenia ksiąg parafialnych (kan. 535 § 1 norma fakultatywna)}

Ostatnią normą fakultatywną powierzoną przez Kodeks konferencji episkopatu jest kwestia wydania przepisów co do rodzaju i sposobu prowadzenia ksiąg parafialnych. Prawodawca w kan. $535 \S 1$ formułuje

45 Kan. 525, nr 2. J. Krukowski, Komentarz do kan. 522-523, w: Komentarz do Kodeksu Prawa Kanonicznego, t. 2, ks. II (1). Lud Boży, red. J. Krukowski i in., Poznań 2005, s. 423.

46 Canadian Conference of Catholic Bishops, Complementary norms to the 1983 Code of Canon Law, Appointment of pastors, can. 522, Decree nr 5 (23 October 1984; recognitio 8 March 1985), Ottawa 1996, s. 39.

47 Tamże. 
zasadę: „W każdej parafii należy prowadzić księgi parafialne, a mianowicie ochrzczonych, małżeństw, zmarłych oraz inne, zgodnie z przepisami Konferencji Episkopatu lub biskupa diecezjalnego. Proboszcz ma czuwać nad tym, by księgi były właściwie spisywane i przechowywane".

Konferencje Episkopatów Stanów Zjednoczonych i Kanady nie skorzystały z możliwości, jaką daje kan. 535 § 1 i konsekwentnie nie wydały norm w sprawie prowadzenia ksiąg parafialnych. Oznacza to, że w każdej diecezji w USA i Kanadzie obowiązują diecezjalne przepisy $\mathrm{w}$ tej kwestii.

\section{Zakończenie}

1) Konferencje Episkopatów Stanów Zjednoczonych i Kanady w zdecydowanej większości wypełniły normy kompetencyjne zawarte w KPK odnośnie do spraw objętych stosownymi kanonami księgi II KPK.

2) Wydaje się, że w kwestii określenia wieku oraz przymiotów mężczyzn świeckich jako kandydatów do posługi lektoratu i akolitatu Konferencje Biskupów Stanów Zjednoczonych i Kanady powinny ustalić także maksymalny wiek do podjęcia tych posług, nadmienić o przygotowaniu początkowym do podjęcia wspomnianych posług i formacji stałej, a także postawić wymóg, w przypadku kandydatów żonatych, uzyskania zgody żony.

3) Celowym wydaje się ustanowienie przynajmniej niektórych norm komplementarnych w zakresie księgi II KPK w sposób ogólny, aby pozostawić pewien margines dla kreatywności normatywnej biskupów diecezjalnych.

4) Udanym rozwiązaniem norm kodeksowych traktujących o ustaleniu trzyletniego programu formacji dla kandydatów do stałego diakonatu oraz programu kształcenia kapłańskiego jest wydanie przez omawiane konferencje biskupie krajowych dyrektoriów w tej materii.

5) Odnośnie do obowiązku noszenia stroju duchownego powinno się wydać konkretne normy, przez co zapobiegnie się nadużyciom, a może nawet zarzuceniu używania stroju kościelnego. 
6) Wydając normy w sprawie utrzymania i mieszkania proboszczów przechodzących na emeryturę, należy mieć na uwadze to, że materia ta jest jednym $\mathrm{z}$ aspektów wynagrodzenia duchownych.

7) Wydaje się, że w sprawie powierzenia kapitule katedralnej zadań kolegium konsultorów słuszna jest norma, która pozostawia biskupowi diecezjalnemu kwestię wprowadzenia jej w życie w swojej diecezji kan. $502 \S 3$.

8) Należy sądzić, że odnośnie do ustalenia nominacji proboszczów na czas określony decyzję powinno się pozostawić biskupowi diecezjalnemu. Winno być to przejawem decentralizacji prawa kanonicznego.

9) Kwestia przepisów co do rodzaju i sposobu prowadzenia ksiąg parafialnych powinna podlegać prawu poszczególnych diecezji.

\section{Bibliografia}

Burkard D., Die Domkapitel und das "regimen ecclesiasticum”. Thesen zu Wandel und Kontinuität einer alten Institution, Rottenburger Jahrbuch für Kirchengeschichte 2014, t. 33.

Cunningham R., Commentary on canon 284, w: New Commentary on the Code of Canon Law, red. J. Beal, New York 2000.

De Santi M., L'abito ecclesiastico. Sua valenza e storia, Ravenna 2004.

Ditewig W., 101 Questions and Answers on Deacons, New York 2004.

Donovan W., National Directory for the Formation, Ministry, and Life of Permanent Deacons in the United States (review), The Jurist. Studies in Church Law and Ministry 2008, t. 68, nr 1.

Fanning W., Chapter, w: The Catholic Encyclopedia, t. 3. Brownson-Clairvaux, New York 1913.

Gerosa L., Canon Law, Münster 2002.

Góralski W., Lud Boży. Kościelne prawo osobowe, Częstochowa 1996.

Krukowski J., Komentarz do kan. 522-523, w: Komentarz do Kodeksu Prawa Kanonicznego, t. 2, ks. II (1). Lud Boży, red. J. Krukowski i in., Poznań 2005.

Martín de Agar J., Estudio comparado de los decretos generales de las conferencias episcopales, Ius Canonicum 1992, t. 32, nr 63.

Models of Priestly Formation. Assessing the Past, Reflecting on the Present, and Imagining the Future, red. D. Marmion, M. Mullaney, S. Ryan, Collegeville 2019. 
Onyems Okwuru Ch., The Responsibilities and Significance of the Congregatio pro Clericis in the life and ministry of the diocesan clergy, Bloomington 2012.

Porter L., The assault on priesthood. A biblical and theological rejoinder, Eugene 2012.

\section{Streszczenie}

Celem artykułu jest ukazanie zagadnienia wydania przez Konferencje Biskupów Stanów Zjednoczonych i Kanady norm uzupełniających do Kodeksu prawa kanonicznego z 1983 r. w zakresie księgi II. Autor przytacza i ocenia poszczególne normy komplementarne wydane przez te konferencje episkopatu. Najpierw omawia normy obligatoryjne, a następnie fakultatywne.

Słowa kluczowe: Kodeks prawa kanonicznego, normy komplementarne, prawo partykularne, lud Boży, konferencja episkopatu

\section{COMPLEMENTARY NORMS TO THE 1983 CODE OF CANON LAW IN RESPECT TO BOOK II ISSUED BY THE EPISCOPAL CONFERENCES OF THE UNITED STATES AND CANADA}

\section{Sum mary}

The purpose of the article is to present the Complementary norms to the 1983 Code of Canon Law in respect to Book II issued by the Episcopal Conferences of the United States and Canada. The author cites and assesses individual complementary norms issued by these fora. Obligatory standards are discussed first, and next, optional norms are analysed. The article ends with conclusions and references.

Key words: Code of Canon Law, complementary norms, particular law, People of God, episcopal conference

\section{НОРМЫ КОНФЕРЕНЦИЙ КАТОЛИЧЕСКИХ ЕПИСКОПОВ США И КАНАДЫ, ДОПОЛНЯЮЩИЕ КОДЕКС КАНОНИЧЕСКОГО ПРАВА ОТ 1983 ГОДА В ОТНОШЕНИИ КНИГИ ІІ}

\section{Резюме}

Цель статьи - представить вопрос выпуска Конференциями католических епископов США и Канады дополнительных норм к Кодексу канонического 
права от 1983 года в отношении Книги II. Автор цитирует и оценивает отдельные дополнительные нормы, изданные этими Епископскими конференциями. Сначала обсуждаются обязательные нормы, а затем - факультативные.

Ключевые слова: Кодекс канонического права, дополнительные нормы, партикулярное каноническое право, Народ Божий, Конференция католических епископов 
